\title{
PRÁVNÍ PORADNA
}

Uvažuji o odchodu ze zaměstnaneckého poměru v nemocnici a založení vlastní ambulance. Hodilo by se mi nějaké shrnutí, jak už ted'plánovat prodej ambulance, abych pak za 25 let nemusel spoléhat jen na státní důchod a měl jsem v záloze přijem z prodeje ordinace.

Vaše otázka v sobě skrývá 2 dílčí otázky jednak otázku, jakou formou provozovat vaši soukromou ambulanci (ordinaci) pro dobu príšštích 25 let, a jednak otázku, jak zvolená forma nakonec ovlivní prodej vaší ordinace po 25 letech.
Ačkoliv plánovat s takto dalekým a širokým horizontem je těžké, existuje jen jedna horší věc, a to neplánovat vůbec.

Proto díky za skvělý dotaz, a protože informačních zdrojů na toto téma je spíše nadbytek, pokusím se o maximálně přehlednou odpověd' a jakýsi rozcestník, který vám pomůže v dalším plánování.

Pro provozování a následný převod ordinace máte tyto možnosti:

\begin{tabular}{|c|c|c|}
\hline Prodávající = VY & Kupující & Nejčastější způsob převodu \\
\hline Fyzická osoba (OSVČ) & Fyzická osoba & Smlouva o koupi závodu (§ 2175 NOZ’) \\
\hline Fyzická osoba (OSVČ) & Právnická osoba & \begin{tabular}{|l} 
Smlouva o koupi závodu \\
Nepeněžitý vklad (§ 17 ZOK²)
\end{tabular} \\
\hline $\begin{array}{l}\text { Právnická osoba (můžete vybírat mezi formami } \\
\text { uvedenými dole) }\end{array}$ & Fyzická osoba & $\begin{array}{l}\text { Převod obchodního podílu ( } \$ \$ 207,208 \text { a } 210 \text { ZOK) } \\
\text { Prodej akcií ( } \$ \S 269 \text { a } 275 \text { ZOK) }\end{array}$ \\
\hline $\begin{array}{l}\text { Právnická osoba, přičemž v úvahu připadá: } \\
\text { - ústav podle NOZ } \\
\text { - s.r.o. dle ZOK } \\
\text { - a.s. dle ZOK } \\
\text { - v.o.s. dle ZOK } \\
\text { - SE dle ZES }{ }^{4}\end{array}$ & Právnická osoba & 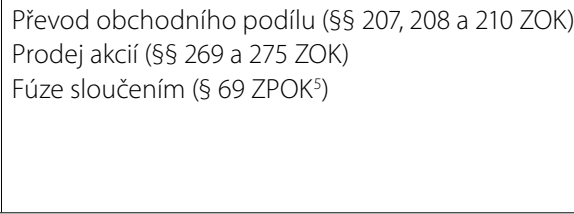 \\
\hline
\end{tabular}

Pro vaše potřeby Ize z těchto možností vybrat 2 nejčastější a nejreálnější:

- provozování ordinace jako společnosti s ručením omezeným a následný prodej obchodního podílu, anebo

- provozování ordinace jako podnikatel fyzická osoba podle § 421 odst. 2 NOZ (OSVČ) a následný prodej ordinace jako tzv. obchodního závodu (jde o pojem používaný občanským zákoníkem a obchodním závodem je myšlen organizovaný souhrn majetku a závazků, které vytvoř́te a budete používat k provozu ordinace).

Cesta k dobré strategii může začít tím, že si stanovíte základní cíle, na které se budete soustředit: i) finanční výhodnost - tj. jaká forma převodu praxe vám přinese nejvíc prostředků pro váš důchodový život, ii) operativnost - tzn. jak složitý a zdlouhavý bude prodej ordinace, a iii) právní jistota - tj. jak velké riziko právních sporů bude spojené s převodem praxe.

\section{Finanční výhodnost}

Pokud jde o finanční výhodnost prodeje, o té rozhodnou dvě složky - jednak výše kupní ceny, kterou se vám podaři vyjednat s kupujícím, a jednak výše daní, které budete muset odvést státu z vyjednané kupní ceny.

Pokud jde o kupní cenu, počítejte s tím, že trh s ordinacemi funguje jako jakýkoliv jiný trh a výslednou tržní cenu určí a) poptávka, b) nabídka a c) vaše vyjednávací schopnosti.
Jaká bude poptávka a nabídka ordinací v roce 2045, nyní neovlivníte, soustřed'me se proto na to, co ovlivnit Ize, a to je síla vaší vyjednávací pozice.

Tu můžete již od začátku výrazně posílit tím, že se dobře připravíte na tzv. due diligence, které se nevyhnete, at již zvolíte kteroukoliv z výše popsaných forem.

Předkupní prověrka (due diligence) je mimo jiné i chytrým nástrojem kupujícího, který díky ní může shromáždit argumenty pro požadavek na snížení kupní ceny. Existují podrobné seznamy všech prověřovaných okruhů, nejdůležitější ale zpravidla bývá nepodcenit tyto okruhy:

- pečlivá a doložená evidence vlastnictví majetku tvořícího ordinaci (jak hmotného, tak i nehmotného - např. licence k softwaru který používáte),

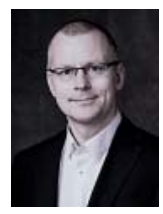

KORESPONDENČNII ADRESA AUTORA:

JUDr. Miroslav Špecián, Ph.D., specian@specian.eu

$\checkmark$ Jámě 1,11000 Praha 1

Cit. zkr: Neurol. praxi 2020; 21(3): 248-249 
- pečlivá a doložená evidence závazků spojených s ordinací,

- pečlivá a doložená dokumentace dodržování všech právních předpisů (zdravotnickými zákony počínaje a GDPR konče).

Pokud jde o zdanění prevodu, zde vychází výhodněji převod obchodního podílu na s.r.o. Pokud ho budete prodávat po 25 letech, pak podle $\S 4$ odst. 1 písm. s) ZDP6 půjde o př́ijem zcela osvobozený. Naopak př́ijem z prodeje obchodního závodu mezi osvobozenými príimy nenajdete a kromě daně z príjmů fyzických osob budete muset dokonce ještě zaplatit navíc i pojistné na tzv. „sociální a zdravotní. Konkrétní výpočet daňové úspory (rozdílu ve zdanění) si ale nechte zpracovat od daňového poradce konstrukce základu daně v obou prípadech je celkem složitá a na internetu se objevují špatné paušální výpočty zpưsobené nepochopením rozdílů mezi jednotlivými základy daně.

\section{Operativnost}

Administrativní složitost samotného soukromoprávního převodu ordinace je u obou způsobů v zásadě srovnatelná.

Jak pro prevod podílu v s.r.o., tak pro převod obchodního závodu u OSVČ je klíčovým bodem smlouva o prevodu (k ní viz další bod o právních rizicích).

Převod podílu v s.r.o. je nepatrně administrativně složitější, protože vyžaduje navíc i (i) úředně ověřené podpisy, (ii) změnu jednatele a (iii) zápis změn do obchodního rejstř́íku. Administrativu si můžete trochu zjednodušit tím, že v názvu (firmě) společnosti nepoužijete

\section{LITERAURA}

1. Zákon č. 89/2012 Sb., občanský zákoník, v platném a účinném znění.

2. Zákon č. 90/2012 Sb., o obchodních korporacích, v platném a účinném znění.

3. Pro váš prípad zcela nevhodná forma, zejména kvůli faktické nepřevoditelnost za finanční úhradu. své jméno a príjmení - tím si ušetříte proces přejmenování (asi nebudete chtít, aby po vašem odchodu do důchodu byla vaše ordinace pořád provozovaná pod vaším jménem).

Poměrně značný rozdíl je ale ve složitosti

veřejnoprávního převodu ordinace minimálně v tomto rozsahu:

- oprávnění k poskytování zdravotních služeb,

- oprávněník úhradě poskytnuté péče z prostředků veřejného zdravotního pojištění,

- povinné pojištění odpovědnosti za škodu způsobenou v souvislosti s poskytováním zdravotních služeb,

- zdravotnická dokumentace.

Při převodu podílu v s.r. o. nezaniká původní oprávnění. Kupující pouze musí pod hrozbou sankce 300000 Kč postupovat podle $\S 21 \mathrm{ZZS}^{7}$ a musí do 15 dnů písemně oznámit a doložit změny údajů uvedených v pưvodním rozhodnutí. Pưjde zejména o oznámení jména, príimení, adresy a data narození nového jednatele a odborného zástupce.

Při převodu podílu v s.r. o. rovněž nezaniká ani smlouva se zdravotní pojištovnou o poskytování a úhradě hrazených služeb (viz čl. 8 rámcové smlouvy dle vyhlášky o rámcových smlouvách ${ }^{8}$ ).

Konečně pak ani v důsledku převodu podílu nezaniká ani pojištění odpovědnosti požadované zákonem (§ 24 odst. 2 písm. b ZZS).

Pokud jde o zdravotnickou dokumentaci, ani ta nebude změnou dotčena, protože nedochází k žádné dispozici s ní (poskytovatel ve smyslu $\S 53$ odst. 1 ZZS zůstává stejný).

Naproti tomu převod závodu OSVČ bude pro kupujícího podstatně složitější v tom, že:

4. Zákon č. 627/2004 Sb., o evropské společnosti, v platném a účinném znění.

5. Zákon č. 125/2008 Sb., o přeměnách obchodních korporací a družstev, v platném a účinném znění.

6. Zákon č. 586/1992 Sb., o daních z příjmů, v platném a účinném znění.
- bude muset mít či získat vlastní oprávnění k poskytování zdravotních služeb podle $\S 18$ odst. 3 ZZS,

- bude muset vyřešit prevod smlouvy se zdravotní pojištovnou, byt prevod je možný mimo výběrové řizení a je poněkud usnadněn $\S 17$ odst. 8 ZVZP',

- prevod pojistné smlouvy může být prímo zakázán ustanovením pojistné smlouvy nebo všeobecných pojistných podmínek.

\section{Právní jistota}

$\checkmark$ neposlední řadě vás bude určitě zajímat to, jak se bude lišit míra rizikovosti obou modelů

Při samotném provozu praxe bude platit, že méně rizikové je provozování cestou s.r.o. $\checkmark$ takovém prípadě nese majetkovou odpovědnost sama právnická osoba a vy budete pouze ručit do výše nesplaceného vkladu. Při výkonu Činnosti jako OSVČ vše konáte na svoji vlastní odpovědnost a odpovídáte do výše svého celého majetku (zasaženo přitom může být i společné jmění manželů).

Pokud pak jde o rizikovost samotného prevodu, daleko větší nároky na formulaci smlouvy klade převod obchodního podniku.

\section{Závěr}

Jako jednodušší a méně rizikové se ze všech výše uvedených důvodů zdá provozovat praxi prostřednictvím společnosti s ručením omezeným. Za největší výhody můžeme považovat jasné a přehledné oddělení majetku a činností ordinace a majetku a činností vás jako fyzické osoby, a také zjednodušení postupu při prodeji vaší praxe po plánovaných 25 letech činnosti.

7. Zákon č. 372/2011 Sb., o zdravotních službách, v platném a účinném znění.

8. Vyhláška č. 618/2006 Sb. kterou se vydávají rámcové smlouvy, v platném a účinném znění.

9. Zákon č. 48/1997 Sb., o veřejném zdravotním pojištění, v platném a účinném znění. 